\title{
Phytoremediation of Ex Mining Lake Water in Constructed Wetland by Perennial Plants
}

\author{
Norhaslina Mohd Sidek ${ }^{1,2 *}$, Nurul 'Uyun Ahmad', \\ Siti Rozaimah Sheikh Abdullah ${ }^{1}$, and Sarifah Fauziah Syed Draman ${ }^{2}$ \\ ${ }^{1}$ Department of Chemical and Process Engineering, Faculty of Engineering and \\ Built Environment, Universiti Kebangsaan Malaysia, Bangi 43600, Selangor, \\ Malaysia \\ ${ }^{2}$ Faculty of Chemical Engineering, Universiti Teknologi MARA, Terengganu \\ Branch, Bukit Besi Campus, Dungun 23200, Terengganu, Malaysia \\ *Corresponding author. E-mail: rozaimah@ukm.edu.my \\ https://doi.org/10.12982/CMUJNS.2020.0038
}

Received: October 9, 2019

Revised: April 1, 2020

Accepted: April 17, 2020

\begin{abstract}
Poor water quality due to heavy metal content in Tasik Puteri can harm people that directly get into contact with it for recreational activities. Thus, this study investigated the phytoremediation potential of locally aquatic plants to remediate the lake water. Scirpus grosus and Eleocharis dulcis were planted in constructed wetlands for 28 days. The water analysis was performed to measure turbidity, total iron (TI), total phosphorus (TP), chemical oxygen demand (COD) and electrical conductivity (EC). After 28 days, S. grosus was observed to be healthier. Fluctuation readings were recorded in turbidity value and considerable decrements in TI, TP, COD and EC. S. grosus exhibits higher removal of TI, EC and turbidity which $95.45 \%, 32.89 \%$ and $40.00 \%$ removal respectively, whilst $E$. dulcis removed $65.28 \%$ of COD. Both plants demonstrated comparable TP removal with $92.04 \%$ and $91.04 \%$ by $S$. grosus and $E$. dulcis respectively. In conclusion, $S$. grosus is proven as the more effective phytoremediator.
\end{abstract}

Keywords: Bioremediation, Constructed wetland, Emergent plant, Mining lake water 


\section{INTRODUCTION}

Tasik Puteri is an ex-mining site of iron ore in Bukit Besi, Dungun, Terengganu, Malaysia. The lake has currently become a famous recreational place for few water activities such as picnicking, kayaking, swimming and jet skiing during the dry season (Sidek et al., 2018). Phytoremediation uses plants through different physiological processes that allow absorption capacity and metal tolerance as described by Girdhar et al., 2014 and Dalcorso et al., 2019. Phytoremediation already considered as an alternative treatment method to the metal pollution in the environment (Hazrat et al., 2013). Constructed wetland (CW) is created for treating pollutants in water and soil which comes from human activities like land recovery after mining or refineries. Recently, the most common phytoremediation method uses $\mathrm{CW}$, a human-made system developed by the combination of plants, soil and microbial (Wang et al., 2014).

High concentration of heavy metals may cause adverse health effect to human life although several are vital to them in low concentration (Zafira et al., 2015). Over exposure of contact between human body and the lake water can be so harmful especially to the skin (Kutty and A-Mahaqeri, 2016). It is due to the toxicity of the residues of heavy metal in Tasik Puteri. It can be carcinogenic and affecting nervous also circulatory system. Due to heavy metal toxicity effects, many conservative treatment methods (e.g. activated carbon adsorption, reverseosmosis, nanofiltration, ion exchange, electrodialysis, chemical precipitation and disinfection) being used to lower its concentrations below the threshold limits (Ismail et al., 2015). However, these methods are generally expensive, labour and energy-intensive, metal specific and can generate secondary waste or sludge. Thus, an alternative method like phytoremediation should be featured since it is low cost, more secure and less detrimental (Ismail et al., 2015). There are several aquatic plants that have been used in the process of phytoremediation to treat industrial water with good result such water lettuces (Pistia stratiotes and Salvinia molesta) and water hyacinth (Eichchornia crassipes) (Sidek et al., 2018).

S. grosus is a native and an annual aquatic plant in Malaysia, locally known as 'Mensiang' or 'Rumput menderong'. This aquatic plant species has high growth rate and with the ability to degrade contaminants (Yusoff et al., 2019). S. grossus is suitable and frequently used in CWs. It is a perennial aquatic bulrush with obvious, triangular and resembling leaf blades, sharp to soft and inflorescences on the stem tips. This species often found growing and spreading open in large colonies and tight clusters in water. It has been proven to remediate heavy metal of $\mathrm{Pb}$ (Tangahu et al., 2013), Fe and Al (Ismail et al., 2017), dye (Almaamary et al., 2017), colour (Ahmad et al., 2017) and hydrocarbon (Al-Baldawi et al., 2015) effectively. E. dulcis (Chinese water chestnut) is also an annual plant which grows in swamps or ponds (Minh, 2014). It has slender stem-like and feathery tubular leaves at the nodes which can grow to about $1.5 \mathrm{~m}$. 
On the upper surface, it is deep green and shiny but hairy and purplish brown at the bottom. It can grow and survive well to land flooded with acidic $\mathrm{pH}$.

Both perennial plants are good at absorbing pollutants like heavy metals, thus, it is crucial to study its efficiency in phytoremediation of the lake water contaminated with mining wastewater. Furthermore, there is no previous study on the potential of phytoremediation using native plants to treat the lake water of Tasik Puteri. Therefore, the objective of this study was to phytoremediate the lake water using the selected plant species in terms of five parameters; turbidity, total iron (TI), total phosphorus (TP), chemical oxygen demand (COD) and electrical conductivity (EC) (Kamaruddin et al., 2013) and considered physical observation of the plants. This project was conducted for 28 days in the dry season in August 2018.

\section{MATERIALS AND METHODS}

\section{Description of research site}

Tasik Puteri is located at coordinate of $4.7667^{\circ} \mathrm{N}, 103.2000^{\circ} \mathrm{E}$ in Bukit Besi, Dungun, Terengganu, Malaysia. It was an ex iron ore mining site that was filled up with ground and rain water to form a huge lake. The area general weather is $30^{\circ} \mathrm{C}$ with the $74 \%$ of relative humidity. The lake water that was collected at the waterfall notch area of the mining lake was then filled in the $\mathrm{CW}$.

\section{Propagation of plants}

S. grosus and E. dulcis, two selected species of emergent perennial plants, were collected from an isolated local marsh in Bukit Besi. The original habitat of the plants is in the same area around the mining lake. Therefore, it was assumed that the growth stages of both plants were same. The roots were pulled apart by hand and the old leaves and roots were cut off. The plants were then replanted in containers for about 2 weeks to ensure it is healthy and mature enough (approximately $30 \mathrm{~cm}$ height) before being exposed to the lake water in the $\mathrm{CW}$.

\section{Constructed wetland setup}

The dimension of $\mathrm{CW}$ was $0.5 \mathrm{~m}(\mathrm{~L}) \times 0.36 \mathrm{~m}(\mathrm{~W}) \times 0.34 \mathrm{~m}(\mathrm{H}) .3$ replicates of CWs were set up for each plant species as shown in Figure 1. (AlBaldawi et al., 2013a). Each chamber was filled with $13 \mathrm{~cm}$ height (approximately $20 \mathrm{~L}$ ) of lake water and $13 \mathrm{~cm}$ height of river sand $\Phi 2 \mathrm{~mm}$ (approximately $25 \mathrm{~kg}$ ) to maintain same height of lake water and sand) as adopted by Al-Baldawi, 2013a.

Constructed wetland design consists of 2 principal types of flow system; free surface flow (FSF) and subsurface flow system (SSF). For this study, FSF system was selected for the set up. 18 healthy plants of both species were 
transferred to the $\mathrm{CW}$ chambers and were placed in a greenhouse at ambient environment. The calculation of \% removal efficiency is shown in Equation (1):

$$
\operatorname{Removal}(\%)=\frac{\text { Initial reading }\left(\mathrm{C}_{\mathrm{o}}\right)-\text { Final reading }\left(\mathrm{C}_{\mathrm{f}}\right)}{\text { Initial reading }\left(\mathrm{C}_{\mathrm{o}}\right)} \times 100 \%
$$

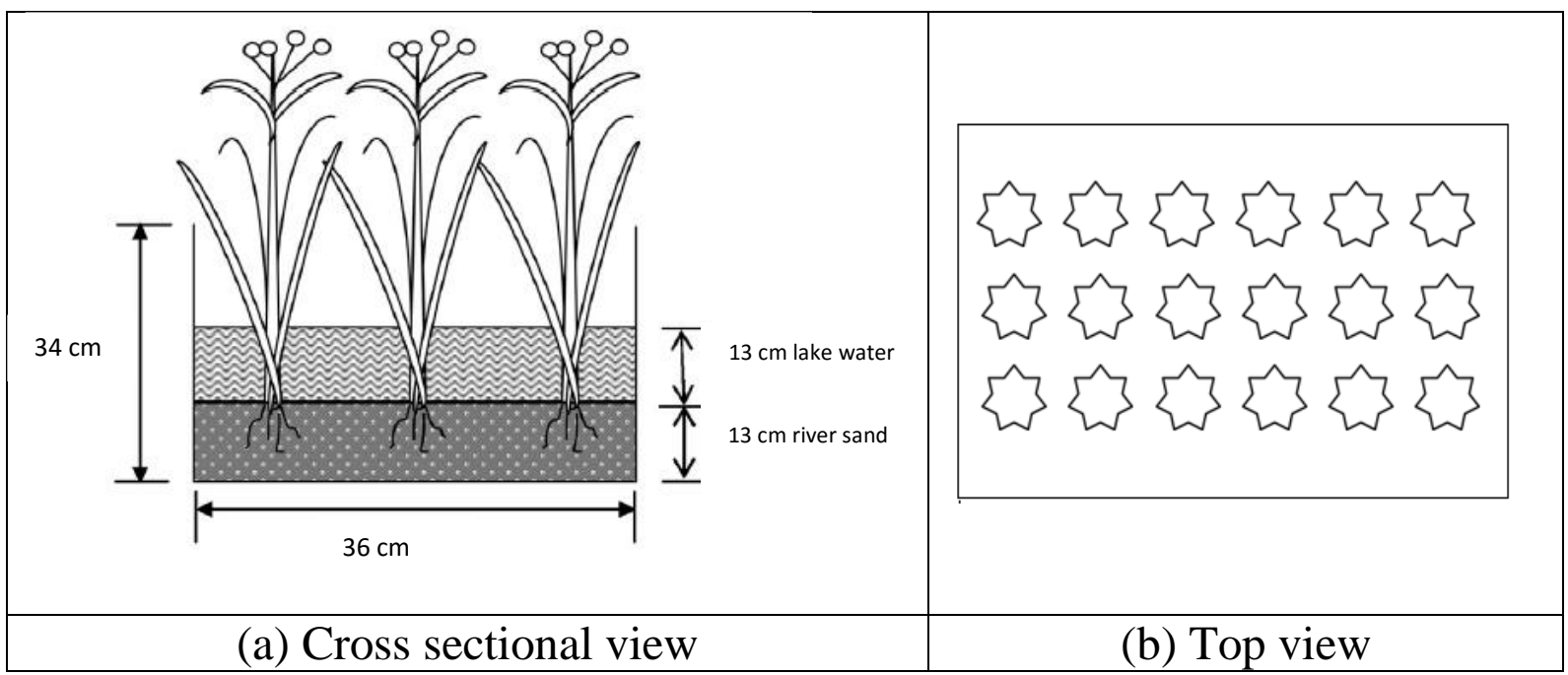

Figure 1. CW set up.

\section{Lake water characterization}

Water samples were collected weekly $\left(0^{\text {th }}, 7^{\text {th }}, 14^{\text {th }}, 21^{\text {th }}\right.$ and $28^{\text {th }}$ days $)$ in clean plastic bottles from each chamber to analyse the concentrations of the contaminants. The water sampling and analysis was performed based on APHA method (1992) (Behailu et al., 2018). To restore water lost due to evaporation, demineralized water was added to the $\mathrm{CW}$ on the treatment day (Al-Baldawi, 2018). The selected five parameters for water analysis were turbidity, TI, TP, COD and EC. Analysis of TI, TP and turbidity parameters was performed using a HACH procedure (USEPA methods) using DR 900 colorimeter, USA, while COD was analyzed using DRB 200 reactor, USA. The EC parameter was determined using conductivity meter equipment, model HQ40d, USA. The water $\mathrm{pH}$ value was also measured using the $\mathrm{HACH}$ procedure to observe the ions speciation effects to the heavy metal removal.

\section{Physical observation}

The plant growth of $S$. grossus and E. dulcis were physically observed throughout the sampling days to examine the survivability in the ex-mining lake water. The freshness, the level of petals survived, and the color of the plants were observed. It was either healthy, withered or died (overall leaves were green, some 
leaves changing colour to yellow or the whole leaves were brown and dried respectively) as discussed by Ismail et al., 2015.

\section{Statistical analysis}

The removal of heavy metal was statistically analysed with GraphPad Prism 8.0.2. A paired-samples $t$-test was used to determine the significance of the difference of heavy metal removal between the two plant species of each sampling day. A significance level of $P<0.05$ was used.

\section{RESULTS}

\section{Characterization of Tasik Puteri lake water}

Table 1 indicates the effluent allowable reading for particular parameters concerned according to the National Water Quality Standards for Malaysia for Class IIA (Recreational use Body Contact) (Malaysia's Environmental Law, Environmental Quality Act, 1974) and the characterization of Tasik Puteri lake water at day 0 .

Table 1. Comparison between standard and $0^{\text {th }}$ day value characterization of lake water sample.

\begin{tabular}{lccc}
\hline \multicolumn{1}{c}{ Parameters } & Units & *Standard & Initial days \\
\hline Total iron & $\mathrm{mg} / \mathrm{L}$ & 1.00 & 2.20 \\
Total phosphorous & $\mathrm{mg} / \mathrm{L}$ & 0.20 & 2.01 \\
Chemical oxygen demand & $\mathrm{mg} / \mathrm{L}$ & 25.00 & 72.00 \\
Turbidity & $\mathrm{NTU}$ & 50 & 10 \\
Electrical conductivity & $\mu \mathrm{s} / \mathrm{cm}$ & 1,000 & 298 \\
$\mathrm{pH}$ & - & $6-9$ & $3-4$ \\
\hline
\end{tabular}

Note: * National water quality standard for Malaysia for class IIA.

\section{Physical observation}

Table 2 demonstrates the transformations of the two aquatic plants on $0^{\text {th }}$ day and $28^{\text {th }}$ day. 
Table 2. Plant physical observation.

Day S. grosus E. dulcis

\section{Total Iron}

Figure 2 represents the removal percentage of TI.

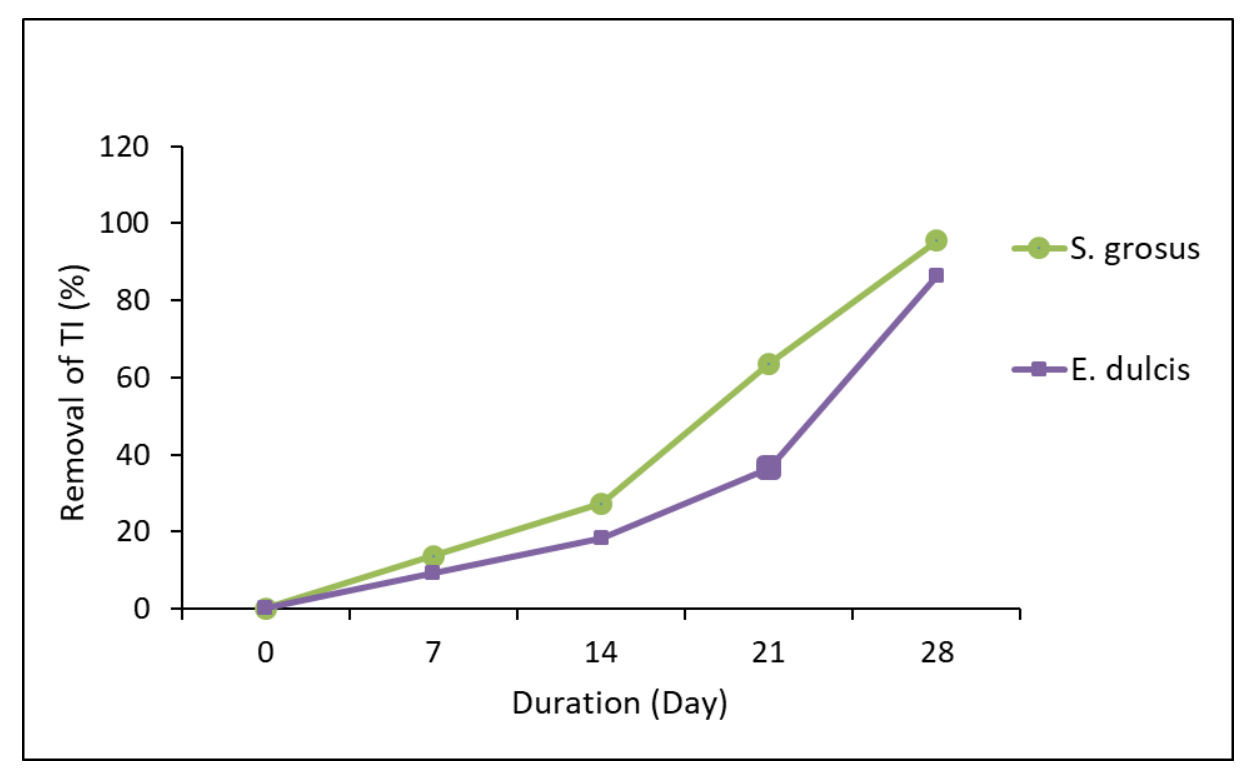

Figure 2. Percentage removal of TI. 


\section{Total Phosphorus}

Figure 3 represents the removal percentage of TP.

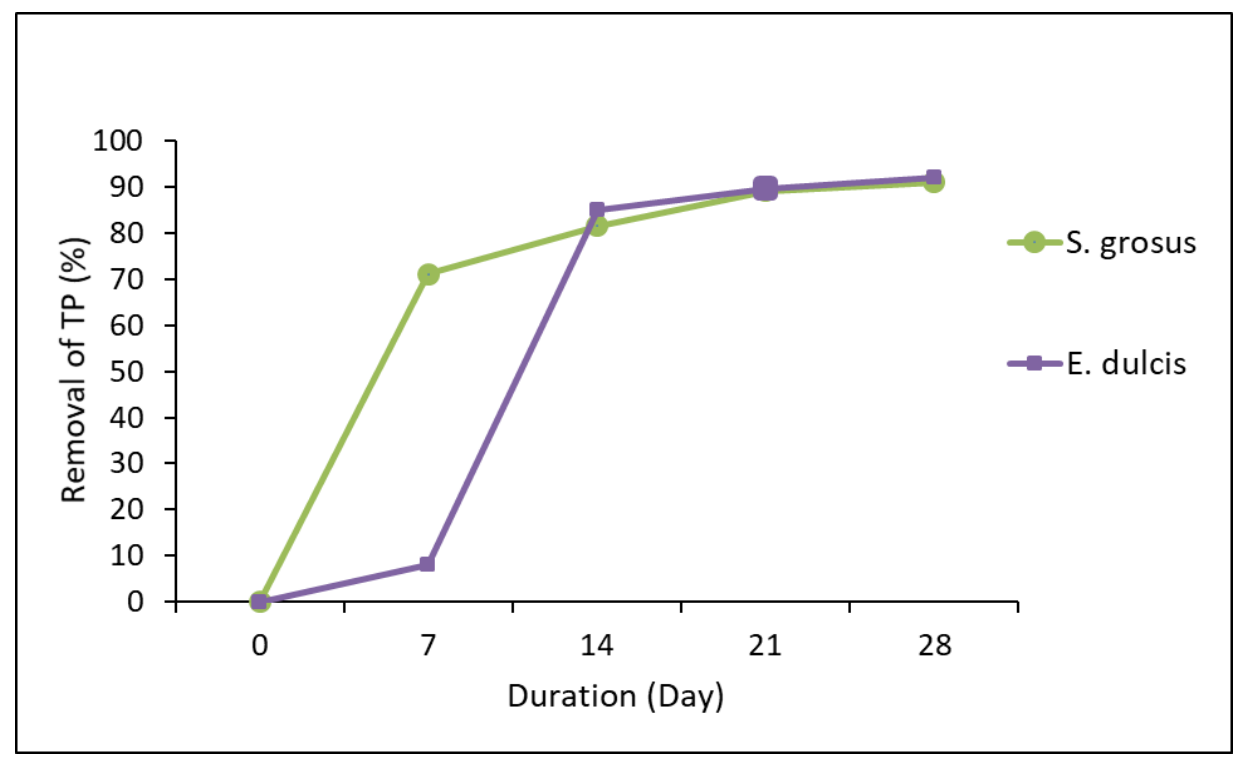

Figure 3. Percentage removal of TP.

\section{Chemical Oxygen Demand}

Figure 4 represents the removal percentage of COD.

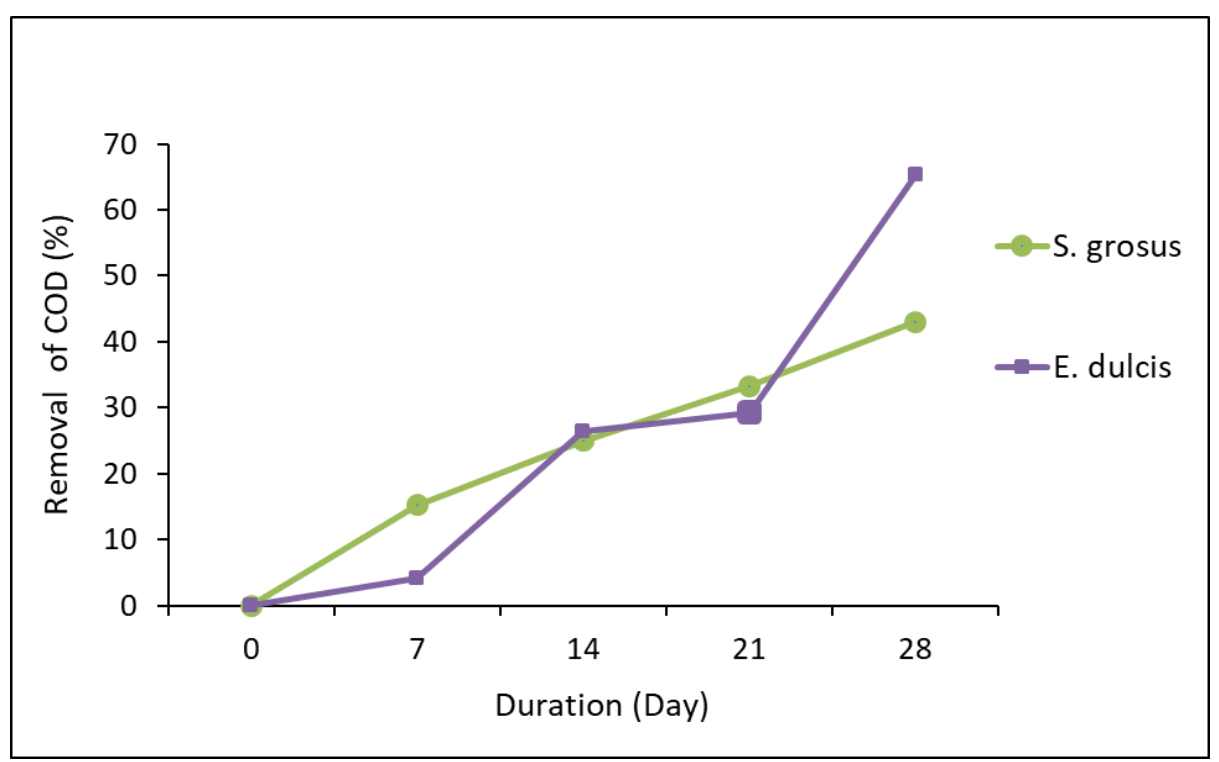

Figure 4. Percentage removal of COD. 


\section{Electrical Conductivity}

Figure 5 represents the reduction percentage of EC.

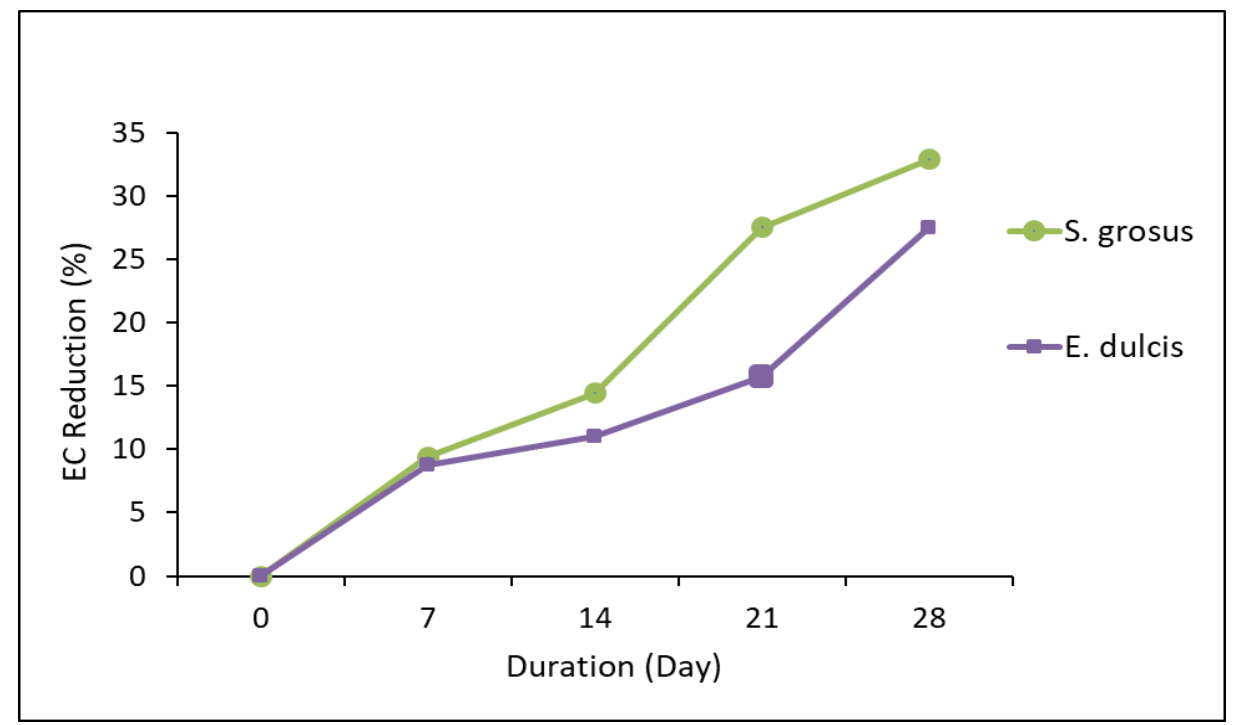

Figure 5. Percentage reduction of EC.

\section{Turbidity}

Figure 6 represents the removal percentage of turbidity.

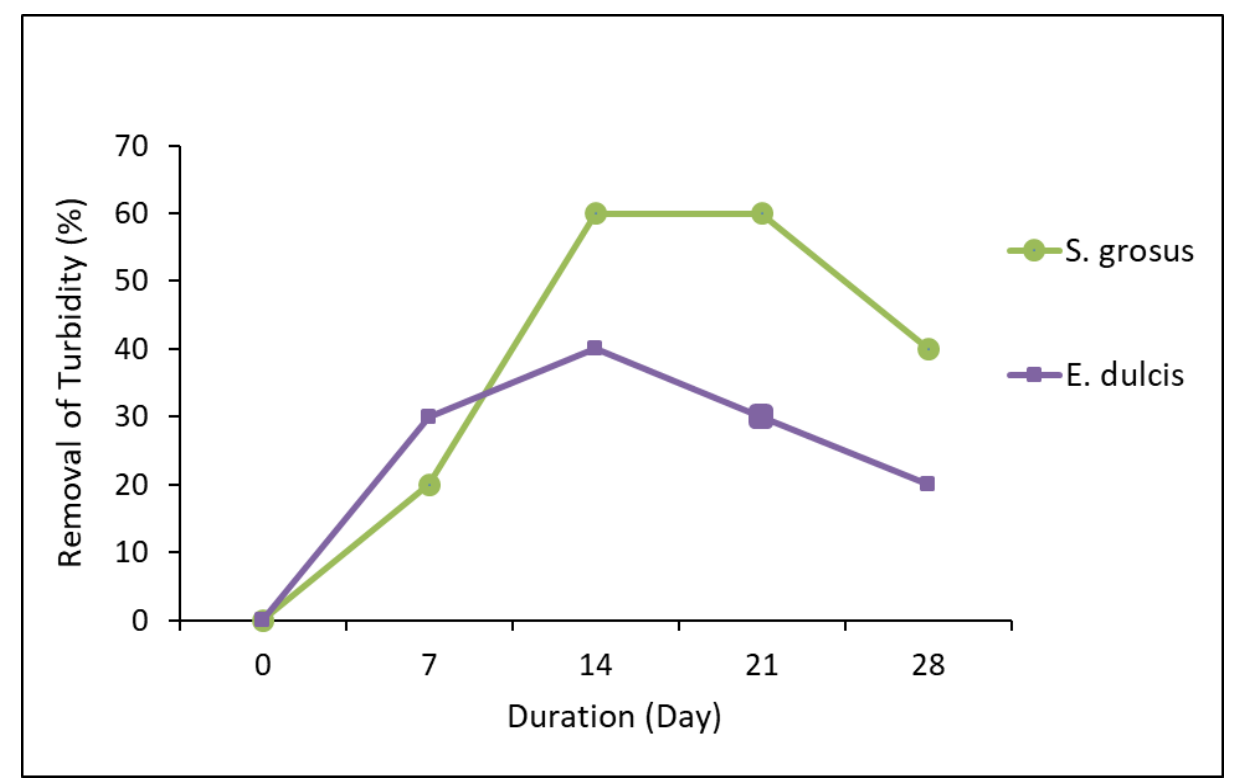

Figure 6. Percentage removal of turbidity. 


\section{Statistical analysis}

Figure 7 represents the statistical analysis of heavy metal removal for five physicochemical parameters.

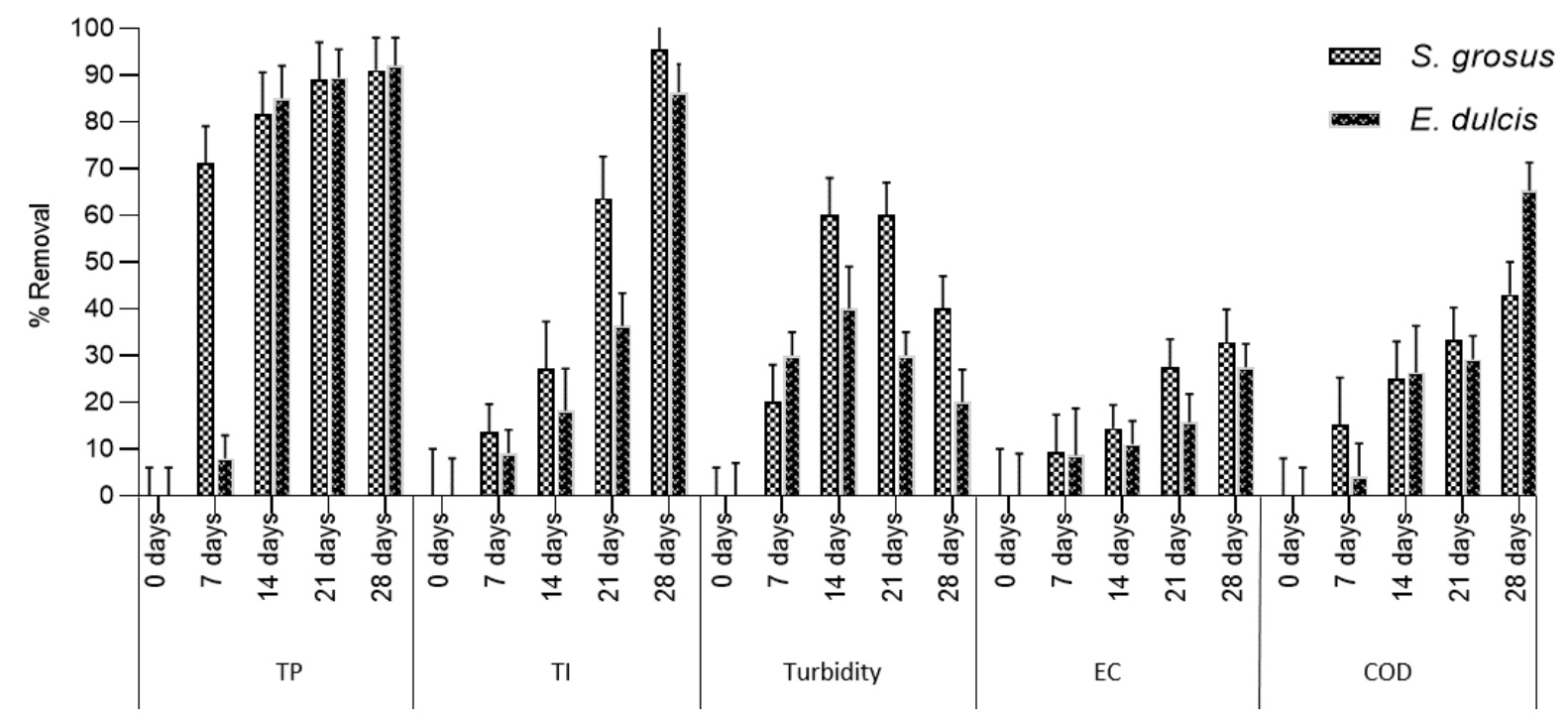

Figure 7. Removal percentage of contaminants after 28 days of exposure. Bars indicate the standard error of the three replicates $(n=3)$. A: difference in contaminants removal between S.grosus and E.dulcis was statistically significant. a: No statisical significance $(P<0.05)$.

\section{DISCUSSION}

The allowable limit of iron, phosphorous and COD content in lake water should be $1.00 \mathrm{mg} / \mathrm{L}, 0.20 \mathrm{mg} / \mathrm{L}$ and $25.00 \mathrm{mg} / \mathrm{L}$ respectively. However, on the $0^{\text {th }}$ day reading of Tasik Puteri lake water, the three parameters were exceeding the water standard, thus requires a water treatment process. All the lake users who directly get contacts with the lake water (especially doing an activity in the lake) in a very long term could expose to the toxicity of the iron and phosphorus which later lead to the major health effect. Fortunately, the turbidity and EC of the lake water show a lower reading compared to the permitted limit. It shows that the lake water is safer to human beings in terms of turbidity and EC. The observed $\mathrm{pH}$ values were in the range of 3 to 4 which was not in the range of acceptable value. Verma and Suthar, 2015 stated that the $\mathrm{pH}$ showed an inverse relationship with removal rate, that indicates a good removal achieved at the acidic $\mathrm{pH}$ of lake water.

Both species were all in good condition on day 0 since no growth inhibition in terms of freshness and colour changes were observed. However, E. dulcis showed rapid reaction over the lake water and turned yellowish after 14 days. On day 28, S. grosus showed a better survival level with no plants were found dead. 
However, E. dulcis were seen withered, as some of the leaves changed to yellowish colour and some were dead. Akinbile et al., 2016 found that the toxic contaminant predominantly inhibited the growth of the root or the upper part of the plant, hence causes the plants to grow unhealthy or die.

The data obtained shows the reduction trend in TI concentration over the period of the experiment. Based on the data collected, the concentration of iron reduced from $2.20 \mathrm{mg} / \mathrm{L}$ to $0.1 \mathrm{mg} / \mathrm{L}$ and $0.3 \mathrm{mg} / \mathrm{L}$ for $S$. grosus and $E$. dulcis, respectively, within 28 days. Figure 2 represents the removal percentage of TI with the highest percentage was accomplished by $S$. grosus which was $95.45 \%$. Heavy metal removal by $S$. grosus from a solution generally involves two stages. The first stage involves the process such ion exchange, chelation and adsorption. Whilst for the second stage, it involves heavy metal precipitation induced by root (Ismail et al., 2017). This plant does phytoremediation by a process called rhizofiltration. They are natural hyper accumulators of many heavy and toxic metals (Al-Baldawi et al., 2013b). In contrast, contaminants that presence in water are being absorbed by the root of E. dulcis. The mechanism of heavy metal removal occurs when an active absorption process takes place. The existence of carboxyl groups at the root system also encourages a remarkable cation exchange through the cell membrane (Prihatini, 2015).

The initial and final concentrations of $\mathrm{TP}$ indicate that the phytoremediation over TP had occurred. The reduction of TP concentrations was from $2.01 \mathrm{mg} / \mathrm{L}$ to $0.18 \mathrm{mg} / \mathrm{L}$ and $0.16 \mathrm{mg} / \mathrm{L}$ for $S$. grosus and for E. dulcis, respectively. Figure 3 demonstrates the percentage removal of TP with similar removal percentages was exhibited by both plants which were $92.04 \%$ and $91.04 \%$ by $S$. grosus and E. dulcis respectively. The TP reading shows a decreasing pattern could be due to the phosphorus consumption by the plant itself. The usage of the phosphorus to the plant are as the medium for biological activity in bio film as well as to provide nourishment essential for plant growth and aesthetic advantage (Al-Baldawi et al., 2018).

Figure 4 represents the percentage removal of COD which shows higher removal by E. dulcis with $65.28 \%$ removal and $43.06 \%$ by S. grosus. The higher COD removal by E.dulcis may be due to its root structure which was more fibrous compared to S. grosus (Yusoff et al., 2019). In addition, the availability of bulky pores and rough structures of the plant roots might greatly accelerate the contaminates adsorption process to happen (Kaur et al., 2016). The declining in COD concentrations is related tremendously to the aquatic plants' activities in the CW. The activity includes a breakdown of organic compound by the microorganisms during phytoremediation. Oxidation of organic matter which contributes energy for microbial metabolism could also be the reason of COD declining occurrence (Azoddein et al., 2015).

The initial value of EC was $298 \mu \mathrm{S} / \mathrm{cm}$ and the final value for $S$. grosus was $200 \mu \mathrm{S} / \mathrm{cm}$. It showed the highest removal efficiency which $32.89 \%$ removal 
as in Figure 5. The EC reduction percentage by E. dulcis was measured as $27.52 \%$ which the final reading was recorded as $216 \mu \mathrm{S} / \mathrm{cm}$. Both aquatic plants showed the capability to remediate the effluent. EC values were seen decreasing due to the salt adsorption process by the plants (Kaur et al., 2016). Normally, conductivity in water is influenced by the existence of inorganic dissolved solids such as sulphate, nitrate, phosphate and chloride anions or magnesium, iron, aluminum, sodium, calcium cations. Conductivity is also affected by the temperature, which the warmer the water, the higher the water conductivity will be (Oyem et al., 2014). Hence, in this study the conductivity measurement was recorded at $30^{\circ} \mathrm{C}$ of lake water. In addition, the previous research already claimed that the decrement of total iron in water, presented the lower reading of EC (Antia, 2015). This supports the fact that the S. grosus and E. dulcis contributed in the phytoremediation process by removing the total iron in the lake water consequently lowering the reading of EC.

Figure 6 shows a fluctuated trend in turbidity removal from the lake water by two aquatic plants. A possible reason on such trend obtained is might be due to the batch system type of CWs. The more efficient turbidity removal was exhibited by S. grosus, reduced from 10 NTU to 6 NTU which indicated $40 \%$ of reduction. Turbidity concentration depends on the concentration of total suspended solid (TSS) value. However the retention time of the process will affect the reduction of turbidity, by which the longer in time the experiment taking place, will increase the turbidity (Akinbile et al., 2016). The increasing of turbidity concentration or total suspended solid in the effluent was possibly due to fragmentation of plant root within the time frame of the experiment was conducted. The gravity factor to settle down the suspended solid was neglected since the plants only tended to die at the end of sampling day.

The values of heavy metal removal for S. grosus and E. dulcis during the 28 days treatment period are shown in Figure 7 . The removal by $S$. grosus was significantly increased 14 days relative to E.dulcis. These results show that $S$. grosus can accelerate the removal of heavy metal from lake water during the first 14 days of exposure. The removal by $S$. grosus was statistically significant compared with $E$. dulcis plant with $P$ value of 0.0342 (paired-samples $t$-test) for all sampling days (Al-Baldawi et al., 2013a).

\section{CONCLUSION}

In conclusion, the percentage removal increases as the time increased shows that both plants perform efficiently as a good heavy metal accumulator. The study found out that both aquatic plants were capable to remediate Tasik Puteri. After 28 days, S. grosus was survived in the lake water, but E. dulcis changed to yellowish and prone to die. $S$. grosus was seen to be more efficient 
phytoremediator to reduce the TI, EC and turbidity compared to E. dulcis. In contrast, E. dulcis exhibited as the more efficient removal of COD and TP removal. Meanwhile, $S$. grosus has higher survivability and adaptability in Tasik Puteri within the experiment period. Overall, both S. grosus and E. dulcis were proven as amongst effective plants in reducing contamination. Thus, phytoremediation using emergent aquatic plants is proven as capable to treat iron ore mining site lake water.

\section{ACKNOWLEDGEMENTS}

The authors would like to express their gratitude to Universiti Kebangsaan Malaysia (UKM) through DCP-2018-006/3 research grant and Universiti Teknologi MARA, Cawangan Terengganu (UiTMCT), Kampus Bukit Besi for providing research facilities and financial support for this project.

\section{REFERENCES}

Ahmad, J., Abdullah, S.R.S., Hasan, H.A., Rahim, R.A.A., and Idris, M. 2017. Screening of tropical native aquatic plants for polishing pulp and paper mill final effluent. Malaysian Journal of Analytical Sciences. 21(1): 105-112. https://doi.org/10.17576/mjas-2017-2101-12

Akinbile, C.O., Ogunrinde, T.A., Man, C.H., and Aziz, H.A. 2016. The Phytoremediation of domestic wastewater in free water surface constructed wetland by using Azolla piñata. International Journal of Phytoremediation. 18(1): 54-61. https://doi.org/10.1080/15226514.2015.1058330

Almaamary, E.A.S., Abdullah, S.R.S., Hasan, H.A., Rahim, R.A., and Idris, M. 2017. Treatment of methylene blue in wastewater using Scirpus grossus. Malaysian Journal of Analytical Sciences. 21(1): 182-187. https://doi. org/10.17576/mjas-2017-2101-21

Al-Baldawi, I.A. 2018. Removal of 1,2-Dichloroethane from real industrial wastewater using a subsurface batch system with Typha angustifolia $L$. Ecotoxicology and Environmental Safety. 147: 260-265. https://doi.org/ 10.1016/j.ecoenv.2017.08.022

Al-Baldawi, I.A., Abdullah, S.R.S., Anuar, N., and Hasan, H.A. 2018. Phytotransformation of methylene blue from water using aquatic plant (Azolla pinnata). Environmental Technology \& Innovation. 11: 15-22. https://doi.org/10.1016/j.eti.2018.03.009 
Al-Baldawi, I.A., Abdullah, S.R.S., Suja', F., Anuar, N., and Idris, M. 2015. Phytodegradation of total petroleum hydrocarbon (TPH) in dieselcontaminated water using Scirpus grossus. Ecological Engineering. 74: 463-473. https://doi.org/10.1016/j.ecoleng.2014.11.007

Al-Baldawi, I.A., Abdullah, S.R.S., Anuar, N., Suja', F., and Idris, M. 2013a. A phytotoxicity test of bulrush (Scirpus grossus) grown with dieselcontamination water in a free-flow reed bed system. Journal of Hazardous Materials. 64-69. https://doi.org/10.1016/j.jhazmat.2013.01.067

Al-Baldawi, I.A., Abdullah, S.R.S., Suja', F., Anuar, N., and Idris, M. 2013 b. Phytotoxicity test of Scirpus grossus on diesel-contaminated water using a subsurface flow system. Ecological Engineering. 54: 49-56. https://doi. org/10.1016/j.ecoleng.2013.01.016

Antia, D.D.J. 2015. Desalination of water using ZVI $\left(\mathrm{Fe}^{0}\right)$. Water. 7(7): 36713831. https://doi.org/10.3390/w7073671

Azoddein, A.A.M., Haris, H., and Azli, F.A.M. 2015.Treatment of Palm Oil Mill Effluent (POME) using membrane bioreactor. Malaysian Journal of Analytical Sciences. 19(3): 463 - 471.

Behailu, T.W., Badessa, T.S., and Tewodros, B.A. 2018. Analysis of physical and chemical parameters in ground water consumed within Konso area, Southwestern Ethiopia. African Journal of Environmental Science and Technology. 12(3): 106-114. https://doi.org/10.5897/AJEST2017.2419

DalCorso, G., Fasani, E., Manara, A., Visioli, G., and Furini, A. 2019. Review heavy metal pollutions: state of the art and innovation in phytoremediation. International Journal of Molecular Sciences. 20(3412): 1-17. https://doi. org/10.3390/ijms20143412

Girdhar, M., Sharma, N.R., Rehman, H., Kumar, A., and Mohan, A. 2014. Comparative assessment for hyperaccumulatory and phytoremediation capability of three wild weeds. 3 Biotech. 2014(4): 579-589. https://doi. org/10.1007/s13205-014-0194-0

Hazrat, A., Ezzat, K., and Muhammad, A.S. 2013. Phytoremediation of heavy metals-Concepts and applications. Chemosphere. 91(7): 1-30. https://doi. org/10.1016/j.chemosphere.2013.01.075

Ismail, N.I., Abdullah, S.R.S., Idris, M., Hasan, H.A., Halmi, M.I.E., Al Sbani, N.H., Jehawi, O.H., Sanusi, S.N.A., and Hashim, M.H. 2017. Accumulation of Fe-Al by Scirpus grosus grown in synthetic bauxite mining wastewater and identification of resistant rhizobacteria. Environmental Engineering Science. 34(5): 367-375. https://doi.org/ 10.1089/ees.2016.0290 
Ismail, N.I., Abdullah, S.R.S., Idris, M., Hasan, H.A., Al Sbani, N.H., and Jehawi, O.H. 2015. Tolerance and survival of Scirpus grosus and Lepironia articulata in synthetic mining wastewater. Journal of Environmental Sciences and Technology. 8(5): 232-237. https://doi.org/10.3923/jest. 2015.232.237

Ismail, N.I., Abdullah, S.R.S., Idris, M., Hasan, H.A., Al Sbani, N.H., and Jehawi, O.H. 2015. Preliminary test of mining wastewater containing iron (III) and aluminium (III) on Scirpus grosus in phytoremediation process. Applied Mechanics and Materials. 773-774: 1111-1115. https://doi.org/10.4028/ www.scientific.net/AMM.773-774.1111

Kamaruddin, M.A., Yusoff, M.S., Abdul, A.H., and Akinbile, C.O. 2013. Recent developments of textile waste water treatment by adsorption process: a review. International Journal of Scientific Research in Knowledge. 1(4): 60-73.

Kaur, K., Mor, S., and Ravindra, K. 2016. Removal of chemical oxygen demand from landfill leachate using cow-dung ash as a low-cost adsorbent. Journal of Colloid and Interface Science. 469: 338-343. https://doi.org/10.1016/ j.jcis.2016.02.025

Kutty, A.A., and Al-Mahaqeri, S.A. 2016. An investigation of the levels and distribution of selected heavy metals in sediments and plant species within the vicinity of ex-iron mine in Bukit Besi. Journal of Chemistry. 2016: 112. https://doi.org/10.1155/2016/2096147

Malaysia's Environmental Law, Environmental Quality Act, 1974. The Malaysia Environmental Quality (Sewage and Industrial Effluents) Regulations, 1979, 1999, 2000, 2009.

Minh, N.P. 2014. Effect of different factors in drying water chestnut corm to supplement into functional instant rice powder. International Journal of Multidisciplinary Research and Development. 1(4): 74-81.

Oyem, H.H., Oyem, I.M., and Ezeweali, D. 2014. Temperature, pH, electrical conductivity, total dissolved solids and chemical oxygen demand of groundwater in Boji-Boji Agbor/Owa area and immediate suburbs. Research Journal of Environmental Sciences. 8(8): 444450. https://doi.org/10.3923/rjes.2014.444.450

Prihatini, N.S. 2015. A study of iron (Fe) uptake by purun tikus (Eleocharis dulcis) from acid mine drainage in subsurface flow constructed wetland. International Conference: Natural, Mathematical and Environmental Sciences. 9-11 October 2015, p.1-6.

Sidek, N.M., Abdullah, S.R.S., Ahmad, N.U., Draman, S.F.S., Rosli, M.M.M., and Sanusi, M.F. 2018. Phytoremediation of abandoned mining lake by water hyacinth and water lettuces in constructed wetlands. Jurnal Teknologi (Sciences \& Engineering). 80(5): 87-93. https://doi.org/10. 11113/jt.v80.10992 
Tangahu, B.V., Abdullah, S.R.S., Basri, H., Idris, M., Anuar, N., and Mukhlisin, M. 2013. Phytotoxicity of wastewater containing lead $(\mathrm{Pb})$ effects on Scirpus grossus. International Journal of Phytoremediation. 15(8): 814-82. https://doi.org/10.1080/15226514.2012.736437

Verma, K., and Suthar, S. 2015. Lead and cadmium removal from water using duckweed - Lemna gibba L.: Impact of $\mathrm{pH}$ and initial metal load. Alexandria Engineering Journal. 54: 1297-1304. https://doi.org/10.1016/ j.aej.2015.09.014

Wang, H.Z., Zuo. H.G., Ding, Y.J., Miao, S.S., Jiang, C., and Yang, H. 2014. Biotic and abiotic degradation of pesticide Dufulin in soils. Environmental Science and Pollution Research. 21(6): 4331-4342. https://doi.org/10.1007/s11356-013-2380-8

Yusoff, M.F.M, Abdullah, S.R.S, Hasan, H.A, Janor, H., and Ahmad, H. 2019. Performance of continuous pilot subsurface constructed wetland using Scirpus grossus for removal of COD, colour and suspended solid in recycled pulp and paper effluent. Environmental Technology \& Innovation. 13: 346-352. https://doi.org/10.1016/j.eti.2018.12.008

Zafira, M., Mohamad, F., and Faradiella, M.K. 2015. Comparing heavy metal mobility in active and abandoned mining sites at Bestari Jaya, Selangor. Environmental Forensics 2015. Procedia Environmental Sciences. 30: 232237. https://doi.org/10.1016/j.proenv.2015.10.042 